\title{
Institutional Contradiction in the Community College
}

By: David F. Ayers

Ayers, D.F. (2009). Institutional contradiction in the community college. Community College Review, 37(2), 165-184. doi: 10.1177/0091552109348042.

\section{***Made available courtesy of Sage Publications: http://ccreview.sagepub.com. No further reproduction is authorized without written permission of Sage Publications. This version of the document is not the version of record. Figures and/or pictures may be missing from this format of the document.***}

\begin{abstract}
:
Critical discourse analysis was employed to examine the narratives collected from 40 community college administrators who were asked to recount their experience in an event, activity, or decision that challenged their values. The analysis yielded three findings. First, contradictions emerged between the administrators' educational and professional values, on the one hand, and managerialism (pressure from above), on the other hand. Second, participants either acquiesced to managerialism or resisted through insubordination or advocacy. Third, the styles enacted by the administrators in the face of these contradictions included the alienated victim (who felt that his or her authority had been usurped), the survivor (who eventually recovered or at least feigned a positive attitude), or the institutional entrepreneur (who successfully aligned a policy or practice with his or her values). The latter successfully advocated for change, suggesting the need for future research on leadership strategies and organizational climates that foster institutional entrepreneurship.
\end{abstract}

\section{Article:}

The community college is a site of institutional contradiction. For decades, scholars have debated these contradictions, and the resulting scholarship has fueled heated controversies about the origins, impacts, and futures of the community college (Dougherty, 1994). Indeed, scholars from functionalist (Clark, 1960; Cohen \& Brawer, 2003; Gleazer, 1968), instrumentalist Marxist (Bowles \& Gintis, 1976; Pincus, 1980; Zwerling, 1976), and institutionalist (Brint \& Karabel, 1989) schools have agreed on very little with respect to the community college. What is not in dispute, however, is that the community college is subject to broader cultural and political economic processes.

Unfortunately, the arguments proffered in these debates assume a 20th century political economy and are not entirely relevant in today's radically different cultural, political, and economic milieu. The impact of these forces on the community college has yet to be fully registered, but what we do know is sobering. For example, Levin (2001) has suggested that today's community college, once oriented to serving local communities, has appropriated more businesslike institutional behaviors, including the ability to accommodate local communities to the imperatives of a globally integrated economy. This change has occurred at a time when corporate executives are household names, either as heroes and villains; "you're fired" is a popular TV show buzzword, and despite recent evidence to the contrary, the private sector has upheld an influential model of fiscal discipline. In light of this aspect of today's culture, the managerialist behaviors 
mythologized from the corporate world are easily imported into the practice of community college administration (Chiapello \& Fairclough, 2002; Giroux, 2002). This development pits economic values against educational values (Levin, 2007; Levin, Kater, \& Wagoner, 2006) and forces community college educators to suffer the friction between two competing discourses. In this view, managerialist administrative practices and their consequences can be viewed as symptoms of broader ideological struggles rather than as purely local events.

The purpose of this study was to achieve a better understanding of institutional contradiction in the community college, the way it is experienced by community college administrators, and its relation to broader societal struggles. Toward this end, the researcher collected narratives from 40 administrators in a large community college system in the southeastern United States. A modified critical incident technique (CIT; Amabile \& Gryskiewicz, 1987; Flanagan, 1954) was employed; the administrators recounted their experience in an event, activity, or decision that challenged their values. Narrative data were subjected to critical discourse analysis (CDA), with attention directed to (a) discourses, or ways of representing certain aspects of the world; (b) genres, or ways of acting through language; and (c) styles, or ways of enacting certain identities (Chouliaraki \& Fairclough, 1999; Fairclough, 2001; Jessop, Fairclough, \& Wodak, 2008).

As is elaborated below, participants repeatedly associated pressure from above with challenges to their values. In fact, the discussion of pressure from above emerged as the only salient challenge. This was an unexpected finding, and to account for these data, the researcher consulted both the academic literature and a wide range of current public and policy documents related to the community college. Through a retroductive process of comparing this literature with administrators' narratives (Archer, Bhaskar, Collier, Lawson, \& Norrie 1998; Sayer, 2000), the researcher interpreted pressure from above as a managerialist discourses characteristic of the current cultural and political economic milieu and recontextualized (Bernstein, 1990; van Leeuwen, 2009) into the practice of community college administration. Though limited to institutional contradictions and discursive struggles experienced by community college administrators in a particular state system, the findings offer insight into the consequences of managerialism on both personnel and academic programming. Findings also demonstrate how community college administrators make meaning of institutional contradiction, how they use language to negotiate contradiction, and how they enact and resist certain roles in the process.

\section{THEORETICAL FRAMEWORK}

The sections that follow include an overview of a dialectical-relational approach to CDA, its aims, and its relation to the study of institutions. Managerialism is then theorized as a discourse that permeates contemporary culture and informs administrative practice across institution types. Its particular manifestation within the practice of community college administration is briefly highlighted, using a segment from a government report as a textual example. Finally, the concept of recontextualization is defined and used to explain the prevalence of managerialism within the practice of community college administration. First, however, it is necessary to define what is meant by discourse in this study.

\section{Theory and Methods of CDA}

The object of this study is discourse. For the purposes of this study, I adopted Kjaer and Pedersen's (2001) definition of discourse: "Discourse is a system of meaning that orders the 
production of conceptions and interpretations of the social world in a particular context" (p. 220). Two key elements of discourse merit elaboration. First, discourse is a system of meaning. When used as a count noun, a discourse is a particular way of making sense of and representing aspects of the world, which entails its own logics and rationalities (Wodak \& Meyer, 2009). Second, because discourse constructs the world from a particular worldview, all discourse functions ideologically. Discourse defines problems, legitimizes solutions, and constructs identities (Gee, 1999, 2001; Wetherell, Yates, \& Taylor, 2001). Language, then, is a means of achieving sociopolitical ends (Fairclough, 1989; Halliday, 1978; Halliday \& Hasan, 1989). In short, discourse is not simply a neutral medium through which ideas and knowledge are communicated, rather it is social action in and of itself. For this reason, discourse has attracted the interest of critical social theorists, precipitating the development of CDA.

CDA is based on an understanding of language use as a force of dominance and ideology but also as a source of resistance and liberation (Fairclough, 1989; Foucault, 1980; Halliday, 1978; Halliday \& Hasan, 1989). It applies linguistic and semiotic analysis toward a social problem, such as structures of dominance, oppression, or unmet needs. Critical discourse analysts assert that society's dominant groups shape the meanings of social and material processes through discourses that reflect their own worldviews and interests. CDA offers a way of illuminating these language practices and critiquing their ideological consequences. In this sense, CDA is an approach to analyzing "opaque as well as transparent structural relationships of dominance, discrimination, power and control as manifested in language" (Wodak \& Meyer, 2001, p. 2). The particular approach to CDA guiding this study seeks to demonstrate the relations among broader societal processes and concrete events, demystify and question the ideological nature of such relations, and propose more democratic and equitable alternatives to current practices.

Discourse and institutions. Central to an understanding of discourse theory are institutions, which may be thought of as socially sanctioned speech communities. In other words, institutions shape to a great extent what can and cannot be said within their domains. Fairclough (1995) positioned social institutions at the nexus of two levels of social structuring. The highest and most abstract level of social structuring is that of the social formation, which includes language and economic systems among others. The social formation may also be thought of as a cultural superstructure (Gramsci, 1972). In contrast, the most concrete level of social structuring is the social event or action. This level entails the myriad actions and interactions of individuals within an institutional context. Fairclough suggested that what can and cannot be said during these interactions is substantially constrained by the institutional setting; thus, institutions play a key role in establishing and sustaining hegemony (Althusser, 1984).

Institutions and hegemony. Marshall (1998) explained that hegemony "involves the production of ways of thinking and seeing, and of excluding alternative visions and discourses" (p. 272). To the extent that dominant groups produce and sustain discourses at various levels of social structuring - particularly institutions - their worldviews gain the status of common sense. Because institutions play a prominent role in establishing hegemony, they are the object of political calculation and governance (Althusser, 1984; Gramsci, 1972; Jessop, 2007). At the very least, educational institutions determine which aspects of culture are transferred to upcoming generations. In light of this societal function, education is seen as a site of acute ideological struggle (Apple, 2004; Engel, 2000; Giroux \& Giroux, 2004; Grossberg, 2005). From this point 
of view, today's educational discourses have achieved dominance not through scientific or technical knowledge but instead through social struggle. In this way, an emphasis on revenue, control, standardization, and efficiency has become dominant in higher education (Giroux, 2002). Levin and his colleagues (Levin, 2001; Levin, et al., 2006) have witnessed similar discourses in operation at community colleges. These ideologies have been described as managerialism (Chiapello \& Fairclough, 2002; Levin, 2006).

\section{Managerialism as Ideology}

Managerialism is an ideology in which a properly trained manager is assumed to be an effective administrator within any industry regardless of that industry's technical core. The technical core of the institution - in the case of academia, the faculty members, and college students - is irrelevant to the role of managerialist administrators, whose priority is to improve efficiency, reduce costs, and impose accountability (Chiapello \& Fairclough, 2002; Giroux, 2002). Following this logic, a competent manager should be equally effective as a hospital administrator, a corporate executive, a public administrator, or a community college president.

Managerialist behaviors predicated on corporate models are increasingly common in postsecondary education, both at the university (Aronowitz, 2000; Birnbaum, 2001; Giroux, 2002) and the community college (Ayers, 2005b; Levin, 2006). This change reflects a culture in which the for-profit sector provides an influential even if mythologized model of fiscal discipline. Such assumptions are hegemonic in that corporate leadership styles are often assumed to be effective within higher education. A text produced by the Commission on Competitiveness demonstrates such an assumption. The author of this text, a community college president, is speaking on the role of community colleges in the global, knowledge-based economy and offers suggestions on how the community college might be transformed to produce competitive workers in a global economy:

Through the creation of strategic partnerships, private/public collaborations and integration of best practice models from corporate America, colleges can begin to transform themselves into highly credible, accountable and competitive centers of excellence. Colleges must look for new ways of forging partnerships and redefining their mission. (Cardenas, 2008)

In this text segment, corporate America provides the model for the community college. Institutional priorities are listed as credibility, accountability, competitiveness, and excellence all keywords in manageralist discourse (Chiapello \& Fairclough, 2002). This text positions the community college in direct relation to national competitive strategies. The community college thus becomes an object of political calculation and governance. In fact, politicians at the highest level of government hold community college leaders accountable to the imperatives of the knowledge-based economy (Ayers, 2005a; Ayers \& Carlone, 2007). Under this mode of governance, accountability is believed to require highly directive administrative practices, which are justified intentionally or tacitly through a discourse of managerialism.

Recontextualization of managerialism. Managerialism, once again, is a prevalent discourse within the current social formation. It did not originate with the community college, of course, but it has become prominent in the practice of community college administration nonetheless. 
This introduction of a discourse from one domain of social life into another is referred to as recontextualization (Bernstein, 1990; van Leeuwen, 2009). Processes of recontextualization may lead to institutional contradiction when newly imported discourses cannot be reconciled with existing discursive traditions within any given institutional setting. Institutional contradictions within the community college may therefore be thought of as incompatibilities between existing discourses and newly recontextualized discourses, although this is only one of many possibilities. Such premises lead to questions about the experiences of institutional actors suffering the friction of incommensurate discourses. At the least, there are tensions between managerialist strategies and techniques, on the one hand, and professional expertise and creativity, on the other hand. As such, the community college is a site of ideological struggle, in this case a contradiction between managerialism and professionalism. This study demonstrates how community college administrators make meaning of this contradiction, how they use language to negotiate these contradictions, and how they take up certain roles in the process.

\section{RESEARCH METHOD}

CDA takes texts as sources of data. In this study, a text is defined as "the discourse moment of social events, meaning not just written texts" but also electronic communications and images, among others (Fairclough, 2006, p. 30). In other words, a text is a concrete realization of social practices, actions, or interactions. A text might be thought of as a materialization or crystallization of discourses. ${ }^{1}$ Accordingly, like its more abstract counterpart, a text is dynamic and not only conveys information but it also functions as a particular way of construing the world and thus constitutes social action.

\section{Data Collection}

To collect textual data, the researcher sent an online questionnaire to a random sample of 200 student services and instructional administrators in the community college system. The questionnaire was based on the CIT, which previous researchers have administered in person and online as a means of understanding individual experiences with a variety of organizational phenomena (Amabile \& Gryskiewicz, 1987; Flanagan, 1954; Johnson, 2002; Keatinge, 2002; Radford, 2006). Community college administrators were first asked to tell a story about their involvement in an event, activity, or decision that challenged their professional or educational values. The questionnaire focused on professional and educational values because these were found to be challenges in previous research (Levin, 2006). Participants were then asked to describe the effect of this incident on subsequent behaviors and attitudes. A total of 160 participants participated in the survey. Of these, 64 responded to the CIT. A total of 24 of these respondents provided superficial responses or responses that did not cohere into a narrative. As such, the researcher collected 40 usable narrative texts. Each text included between 104 and 1,580 words per response. The limited response rate may have narrowed the scope of discursive variation to be studied, which could be viewed as a limitation. However, 40 is a robust number of participants for qualitative research. As well, the purpose of this study was not to survey the entire range of discursive variation in the community college. Instead, the purpose of the study was to under-stand individual administrators' experiences with institutional contradiction. The methodology therefore is not subject to the assumptions and requirements of deductive logics, such as representative sampling. 
To contextualize the data, participants were asked to provide personal and institutional information. Personal data included (a) gender, (b) ethnicity, (c) job title, (d) functional unit of the college, (e) years of experience in community colleges, and (f) education. Institutional data included the location of the institution (urban, suburban, rural) and the size of the institution in terms of enrollment (small, less than 2,500; medium, 2,500 to 7,500; large, more than 7,500), based on the classification system developed by Hardy and Katsinas (2006). The questionnaire also included questions about when the event occurred (within the past year, 2 to 5 years ago, and more than 5 years ago), whether the participant viewed the experience as positive or negative, and the frequency with which similar events occur (very infrequently, infrequently, I'm not sure, frequently, and very frequently).

Participants and their institutions. A total of 40 community college administrators provided complete and usable responses to the online questionnaire, including 24 women and 16 men. A total of 33 described themselves as White; 4 as Hispanic or Latino, regardless of race; 2 as Black or African American; and 1 as American Indian or Native American. A total of 26 were affiliated with student services, 12 with instructional administration, and 2 had responsibilities within both areas. A total of 8 of the participants held a title of vice president or assistant vice president; 8 were deans, 11 were directors, registrars, or coordinators; 11 were counselors; and 2 were department or division chairs, at least 1 of which also held instructional responsibilities. All participants held bachelor's degrees. All but 2 held master's degrees, primarily in counseling ( $\mathrm{n}=$ 13) and in higher education administration, student personnel administration, or community college leadership $(n=8)$. A total of 14 held doctorates, primarily in higher education or community college leadership $(n=9)$. Participant's years of experience in community colleges ranged from 2 to 34, with a mean of $9.29(\mathrm{SD}=8.3)$. Participants described their colleges as rural $(n=21)$, suburban $(n=5)$, and urban $(n=14)$ and as small, less than $2,500(n=13)$; medium, 2,500 to 7,500 $(n=15)$; and large, more than 7,500 $(n=12)$. A total of 20 participants (50\%) described an event that occurred within the past year, 12 (30\%) in the past 2 to 5 years, and 8 (20\%) more than 5 years ago. A total of 15 participants (37.5\%) described the event as a positive experience, whereas 25 (62.5\%) described it as negative. Finally, the frequencies with which similar experiences occur on the job were reported as follows: very infrequently, 12 (30\%); infrequently, 17 (42.5\%); I'm not sure, 3 (7.5\%); frequently, 7 (17.5\%); very frequently, 1 (2.5\%). Given the limited response to the questionnaire, the reader is cautioned not to draw inferences from these statistics, which are provided only for context.

\section{Data Analysis}

The functional aspects of language have been studied intensely by systemic functional linguists who have identified ideational, interpersonal, and textual functions of language (Halliday, 1978; Halliday \& Hasan, 1989). Fairclough (2003) built on this literature and has established three ways that discourse functions as social action: discourses, genres, and styles. Each of these is defined in turn.

Discourses. First, discourses are particular ways of making meaning of and representing some aspect of the social world. Discourses are political in that they construe reality from a certain perspective; thus, other possible perspectives are neglected or never imagined. The question guiding the analysis of discourses was the following: How did participants represent their 
experiences? In other words, how did participants make meaning of their experiences with institutional contradiction?

Genres. Second, genres are ways of acting or interacting textually. Genres are assemblages of language that ascribe to predetermined conventions. Political parties, for example, may enact generic conventions, such as press releases, interviews, articles, books, press conferences, and so forth as ways of shaping public opinion (Wodak, 2001). The guiding question related to genres was the following: How did participants act socially?

Styles. Third, a style is a way of being. It is a socially constructed identity in its semiotic aspect (see also Gee, 1999, 2001; Holland, 1998). The guiding questions related to styles is the following: (a) What styles did participants enact through textual production? and (b) What styles are imposed on coworkers involved in discursive contests?

Coding of texts proceeded according to the questions presented above. The researcher then collapsed codes into salient themes, which were then compared once again with the data. Based on the results of the comparison, the coding scheme was refined and texts were recoded. One code related to challenges that emerged as prominent. This code was pressure from above. Once again, this was an unexpected finding, which required the researcher to return to the literature to construct an interpretive framework that could account for the data. Through a retroductive process (Archer et al., 1998; Sayer, 2000), the researcher sought to identify and explain broader cultural mechanisms that might account for the salience of pressure from above. He constantly compared data with a broad body of scholarly literature; with policy texts produced by community colleges, community college systems, and the American Association of Community Colleges; and with state and federal documents featuring the community colleges. The researcher sketched diagrams, formulated running hypotheses, tested rival hypotheses, and considered contradictory evidence throughout various iterations of analysis.

\section{FINDINGS}

The discussion of findings is organized in terms of (a) discourses, or an explanation of how administrators experienced, or made meaning of, institutional contradictions; (b) genres, or the ways in which participants deployed discourses to negotiate these contradictions; and (c) styles, or an elaboration of three archetypal identities constructed by the textual data.

\section{Contradictory Discourses}

Pressure from above. One overarching theme emerged as dominant in this analysis: a contest over managerialism, on the one hand, and professional autonomy and educational values, on the other hand. Although many discourses circulate through the community college, participants tended to focus on their frustrations with managerialist behaviors. This result was a weakness in that it did not allow for exploration of varied discursive contests, but it was a strength in that most participants contributed data toward this theme. In other words, most study participants had experienced this contest in one way or another, suggesting a prevalence of managerialism in this institutional setting. The term pressure from above was used to describe study participants' frustrations with managerialism, and the researcher selected this term as an in vivo code to represent this broader theme. These hierarchical relations were generally represented as autocratic interventions by presidents, vice presidents, deans, and unspecified supervisors into 
the technical core of the institution, specifically, the daily activities and decisions of participants at various levels of organizational hierarchy.

Pressure from above was most often associated with intrainstitutional forces, although in a few cases it was attributed to processes beyond the level of the institution. As one example, a student services administrator struggled to reconcile an educational discourse of meeting student needs with a federal policy that forced on students a predetermined and constraining goal of job retraining:

Displaced workers receiving federal retraining assistance under the Trade Act are limited to certain programs that others have determined are employable, regardless of the talents, needs, and wishes of the students. If they want the scholarships, and unemployment checks, they have no choice but to comply, so I help them choose a major.

This representation of institutional contradiction recognizes federal involvement in institutional governance. In other cases, the sources of institutional contradiction were attributed to state funding policy. These extrainstitutional explanations of managerialism were the exception rather than the rule, however. Managerialist discourses, once again, were typically represented as local phenomena.

Pressure from above versus professional autonomy. Though some study participants acquiesced to pressure from above, most resisted. On these accounts, struggles were legitimized through professional discourses of ethics and specialized knowledge, which was acquired through professional education and experience. Ethical issues involved treatment of students, hiring and firing of personnel, alleged cronyism, and confrontations with racism, religious intolerance, or sexism. Specialized professional knowledge prompted study participants to take a stand to comply with federal privacy laws, fair hiring practices, legal termination of personnel, and basic standards of professional care. In some cases, administrators resisted initially only to acquiesce later. For example, in the early phase of a conflict episode, an administrator refused to carry out an administrative directive: "I told the [administrator] that this was not ethical and that I didn't agree with his decision. He told me that I would follow his order or there would be repercussions." In the face of this threat, the student services administrator acquiesced to the supervisor's demands.

In other cases, participants successfully advocated for their positions, as the text segment below demonstrates.

A former [executive administrator] wanted to set short, specific time limitations for how much time could be spent with individual students... I felt that this violated our professional standards. For example, working with a student mother of 5 children whose husband had left her that morning and who was terrified about how she would pay her mortgage and care for her children was obviously not a 15-minute activity. I met with the [administrator] and shared specific examples of student needs and detailed why professional[s] ... could not adhere to such an edict. 
In this case, the student services administrator successfully negotiated the contradictions between a managerialist discourse of efficiency and a traditional community college discourse of helping at-risk students. The result was restored levels of professional autonomy.

Pressure from above versus academic values. In addition to professional ethics and knowledge, study participants also engaged an educational discourse of academic values. A repeated example was that study participants on three different campuses expressed concern over an extended late registration period. In these cases, colleges would receive state funding for students who registered late in the semester, so the decision to extend late registration was interpreted as an effort to boost enrollment and thus to increase revenue. This logic was represented as a market-oriented discourse disassociated from the educational goals of the institution.

Study participants also experienced pressure to accommodate student requests for grade changes. In all cases but one, study administrators confronted their supervisors and advocated on behalf of the faculty members who had assigned the original grade. The rationale for defending the faculty members rested on an educational discourse of academic standards. In other instances, administrators resisted managerialist demands to accommodate students by overriding policies related to class attendance, financial aid, and academic integrity. Along with an educational discourse of standards, many of these administrators also engaged an educational discourse of student responsibility:

I continue to support students and act as their advocates when the situation warrants. However, the college must offer strong educational programs that require the students to put forth their best efforts and not look for an easy way out.

In this specific case, the administrator had struggled to enforce a satisfactory academic progress policy, despite pressure from a supervisor "to do whatever necessary to get a more positive outcome in the student's favor." Academic administrators were often unsuccessful in negotiating for their values. In one case, for example, an academic administrator expelled a nursing student, citing unsafe nursing practice, but a supervising administrator overruled the decision. The supervising administrator justified the action through a discourse of student success, which further demonstrates contests between core institutional values.

\section{Genres}

The dominant communicative action reported by participants was advocating or reasoning with supervisors; however, some participants flatly refused to comply with supervisors' demands, and others acquiesced despite having ethical reservations. As an example of advocacy and reasoned argument, a student services administrator had struggled to secure funding for two students to attend a conference. Through persistence and skillful advocacy, "I was able to strongly advocate for both students to attend and they finally found the money for both. So I feel that what I did was valuable and helpful to the students." The verb advocate seemed to resonate with participants, and their facility in recounting related experiences points to advocacy as a chief strategy for negotiating managerialist discourses. 
Participants described a variety of behaviors similar to advocacy, ranging from explaining and negotiating to pleading. The following quote demonstrates the latter:

The director of distance education wanted us to offer online [science] classes with online ... labs. I believe this is a bad idea because [science] labs cannot be adequately simulated in the online environment. I pleaded my case to the dean and VP, and we will not offer online chemistry labs. "[italics added]"

One interesting aspect of this particular situation was that the study participant represented this success as a temporary victory and suggested that she eventually may succumb to pressure to offer online science labs.

One unexpected finding related to genre as social action was that many participants reported insubordination or direct refusal to comply with supervisors' mandates. This mode of resistance is evident in the quotations that follow:

"Pressure" to approve a grade change without faculty concurrence ... Professional[ly] stood my ground and did not do so. Eventually it "went away."

I was asked to change a residence status to in-state when the student was clearly out of state. I did not make the change.

I was asked to release a transcript without written consent by one of my superiors. I felt pressured by them to send the transcript, but I refused to send it with out written consent.

[A member of the community] ... requested the mailing addresses for all of the college's current students. That college did not define mailing address as part of its directory information making it appropriate to share without student's written consent. Therefore, I denied the request.

In these cases, study participants resisted pressure from above with a flat refusal. Based on the experiences of these study participants, flat refusal to implement a managerialist directive often proved to be successful, although study participants indicated a sense of continued antagonism up and down the organizational hierarchy.

\section{Styles}

Alienated victims. The textual data construed three styles: the alienated victim, the survivor, and the institutional entrepreneur. First, alienated victims either conformed to administrative mandates that challenged their values or withdrew, either by retiring, resigning, or psychologically distancing themselves from their work. The four text segments below represent this style:

[These incidents] ... add to my feelings of being jaded; it is stressful and depressing to deal with displaced workers who are my age or older who are suddenly thrust into college with little guidance or support. 
I feel the environment is shifting to a more political one. I second guess my decisions now, something that I did not feel was necessary before. My attitude is much more pessimistic now. I wanted to begin work on my doctorate. Now I think I'll just wait out until retirement.

[This experience has] ... changed my attitude because it doesn't appear that anyone is truly concerned about a good student experience. It appears that we are more concerned with head counts.

Since I have [more than 30] years of employment, I'm resigning this month.

The consequences of discursive contradictions on the alienated victim are disturbing and beg further explanation: Why did study participants take on this style? Alienated victims commonly explained how their authority had been usurped, how they felt attacked, and how their freedom to make professional decisions was undermined. It seems likely that such styles can be explained, at least in part, as a result of an autocratic organizational climate (Baker, 1992; Likert, 1967; Litwin \& Stringer, 1968; Stringer, 2002) — a possibility that is discussed below.

Survivors. Second, survivors also described acts of resistance only to be rebuked, reprimanded, or demeaned by supervisors.

President wanted to move ... [a] ... director immediately. My role was to advocate for the director since this area reports to me ... It [the conflict] escalated ... and the director resigned ... I was very sad for awhile but soon removed my emotions and continued to make decisions to promote the college's best interest.

[An executive administrator] was very controlling and dictatorial. [The administrator] never listened to advice and was very threatened by ... subordinates who had good ideas. [The administrator] took my job apart, moved me from a nice second floor office to the basement of an older building to a desk with holes in it. [The administrator] destroyed the relationships I had built [with the community] ... It has taken me 3 years to recover the programs and regain my sense of being sure I was doing the right thing.

[In this situation] I felt that my authority in my position ... had been undercut without good reason ... [Now] if I am going to make a critical decision about a student or employee, I make sure my boss is going to back me up before I follow through on the decision ... Then if I feel I need to "stick my neck out" due to strong conviction, at least I will be forewarned of the boss not agreeing with my decision.

Unlike alienated victims, survivors had eventually recovered, or at least feigned, a positive attitude. They were able to continue doing what they believed to be right, in the long run seemingly undaunted by adversity. As a general rule, however, these survivors were not as far into their careers as the alienated victims. As such, the survivor may eventually transform into the alienated victim. 
Institutional entrepreneurs. Third, some administrators successfully aligned a policy or practice with their professional or educational values. The broader literature on institutional theory identifies institutional contradictions such as the contest between managerialism and professionalism as an opportunity to promote institutional change. Referred to in this body of literature as institutional entrepreneurs, ${ }^{2}$ these change agents "have an interest in particular institutional arrangements and ... leverage resources to create new institutions or to transform existing ones" (Maguire, Hardy, \& Lawrence, 2004, p. 657). Institutional entrepreneurs exploit institutional contradictions by pitting one discourse against another in ways that shift the balance of power and lead to change.

In this study, institutional entrepreneurs tended to be at the midpoint in their careers, although some had nearly 30 years of experience. Institutional entrepreneurs in this analysis were defined by their achievement of praxis or a successful alignment of institutional processes with professional or academic values. Once again, this change was realized by pitting one institutional discourse against another, as the following text segment demonstrates:

Event: Campus observation of World AIDS Day ... allowing the county health department to show an AIDS information movie and make distribution of free condoms after the showing. Our VP felt it was inappropriate to distribute condoms to the general college student population (what would the administration and board of trustees think). I felt it was appropriate and long overdue since our county has been on top of the state's list for having high incidents of substance abuse, HIV/AIDS, teenage pregnancy, [high school] dropout, and unemployment. I explained that if allowed with the presentation, we were in a great position to make community/attitude/behavior changes ... educating our students is what we are about ... especially when it comes to health care and the importance of using protection (e.g., free counsel, contraceptives, medical checks, etc.) to minimize the spread of STDs in our communities and avoid unwanted pregnancies.

The participant understood this scenario as a contest between an administrator's concern over the college's public image on the one hand and an opportunity to promote learning and social change on the other. The latter discourse of community-based programming and attention to the needs of local constituents is a historical feature of the institution. The former discourse is a pragmatic strategy for avoiding controversy. Administrators are keenly aware of institutional dependence on community support, and public relations are often paramount in the minds of executive administrators. This participant explicitly identified the board of trustees as the governing body to whom the vice president was accountable, demonstrating the effect of governance at levels of hierarchy above the college administration. Following this event, this participant, like many other institutional entrepreneurs in this study, reported feelings of confidence and willingness to take future risks to advance their values.

\section{DISCUSSION AND RECOMMENDATIONS FOR FURTHER RESEARCH}

In this study, the researcher explored community college administrators' experiences with institutional contradiction. With CDA as an analytical framework, the researcher focused on discourses, genres, and styles. This study resulted in three findings. 
First, participants in the study experienced contradiction between professional or educational values, on one hand, and managerialism described as pressure from above, on the other hand. It is important to note that participants associated managerialism with local administrators: The broader societal mechanisms likely associated with administrative directives did not come into view except in a few cases. Community college leaders may attempt to shield the campus community from political-economic turbulence in the external environment. Without an understanding of such external pressures, the campus community may misunderstand leadership behaviors, interpreting them as countereducational when, quite possibly, these behaviors emerge from a constrained choice between two or more suboptimal possibilities. Accordingly, community college leaders may want to conceive of colleges as dynamic, open systems - even self-organizing systems in which organizational processes continually adapt in response to chaotic environmental turbulence (Bergquist, 1998; Gryskiewicz, 1999; Pascale, 1999). Such adaptation, however, requires an awareness on behalf of the campus community of the challenges in the broader cultural and political-economic milieu (Ayers, 2002). Particularly in light of the current economic downturn, community college leaders at all levels can expect increasingly close governance and escalated demands to align educational programs with the imperatives of political economy; yet such pressures may conflict with discourses of professional autonomy and educational values. If so, the ability to negotiate power and interests (Cervero \& Wilson, 1994, 2006; Cervero, Wilson, \& Associates, 2001) is of paramount importance for community college leaders.

Second, in the face of contradiction, some participants acquiesced to administrative mandates, whereas others resisted. When advocacy for educational and professional values wanes or is discouraged, the result can be interpreted as dysfunctional conflict. One classic example of such conflict is the Space Shuttle Challenger disaster, in which reservations - even heated discussions - about the safety of a subfreezing shuttle launch were suppressed. In this tragic case, the executive administrators who gave final authorization to launch the space shuttle never knew about the conflict and potential for disaster (Johnson \& Johnson, 1994). The lesson here is that conflict processes are often essential for organizational effectiveness.

In this study, the communicative behaviors of those who resisted managerialism included both flat refusal and advocacy. Although both of these strategies proved somewhat effective, the latter avoided antagonisms up and down the organizational hierarchy. Institutional entrepreneurs in a study conducted by Perkmann and Spicer (2007) engaged in three types of projects: interactional projects, technical projects, and cultural projects. In the present study, institutional entrepreneurs engaged in cultural projects primarily by espousing historical discourses characteristic of the community college, such as commitment to local issues and academic standards. In such cases, institutional entrepreneurs effected change by appealing to existing cultural values within the practice of community college administration.

Third, three styles emerged from the data: alienated victims, survivors, and institutional entrepreneurs. Managerialism took a toll on alienated victims in this study, and the survivors may be at risk of suffering the same disengagement. However, institutional entrepreneurs successfully countered managerialist discourses with educational and professional discourses. The data did not explain why actors enacted entrepreneurial styles while others did not, but this question is important and begs further study: Why did some participants enact entrepreneurial 
styles, whereas others took on a style of alienated victim or survivor? As mentioned above, institutional factors may explain these differences, particularly organizational climate.

Explained as the answer to the question, "What is it like to work here?" (Baker \& Hoover, 1997), organizational climate has been directly associated with leadership and management styles. In fact, the managerialism represented in this analysis bears close resemblance to autocratic management styles (Likert, 1967; Litwin \& Stringer, 1968; Stringer, 2002). Ironically, these styles are less likely to promote institutional effectiveness, less likely to arouse motivation, and — in community colleges — less likely to promote desired learning outcomes (Baker, 1992; Baker \& Hoover, 1997). However, more participative organizational climates have been shown to facilitate productive communication between institutional actors and their supervisors during episodes of conflict, including negotiation of competing discourses (Ayers, 2002; Pettit \& Ayers, 2002). Furthermore, transformational leadership can only occur when a leader appeals to deeply felt convictions and cultural values (Baker, 1992; Bass, 1998; Burns, 1978). The repression of values is therefore the antithesis of transformational leadership. Finally, the idea of corporate leadership as highly directive and autocratic, while true in many cases, is not a steadfast rule. In fact, leaders in the corporate world and even in the military have found more effective strategies for effecting change (Gryskiewicz, 1999; Heifetz \& Linsky, 2002; Pascale, 1999; Pascale, Millemann, \& Gioja, 2000). Based on this body of literature, more research on the discursive features of organizational climate is needed, especially as it relates to institutional entrepreneurship. Specifically, how can community college leaders encourage organizational climates that cultivate entrepreneurial behaviors?

\section{CONCLUSION}

Conflict is inevitable with an institution as contradictory as the community college. The Chinese symbol for conflict includes two characters: one for danger and another for opportunity (Hocker \& Wilmot, 1985). Similarly, the findings of this study portray conflict as both a danger and an opportunity for desired change; however, desired change requires institutional entrepreneurs who can advocate for their values even in opposition to power. The findings of this study suggest a need for continued research on leadership strategies and organizational climates that cultivate institutional entrepreneurship. Without such an understanding, community college leaders may adopt ineffective administrative practices thought to be characteristic of other settings and unwittingly suppress traditional community college values. Conversely, given optimum organizational climates, institutional entrepreneurs may successfully advocate for principled change.

\section{DECLARATION OF CONFLICTING INTERESTS}

The author declared no potential conflicts of interests with respect to the authorship and/or publication of this article.

\section{FUNDING}

This research was funded by a grant from the Council for the Study of Community Colleges.

\section{NOTES}

1. It should be noted that multiple discourses may be woven together within any given text. 
2. This term is inconsistent with popular meanings; however, I chose to retain the term to remain consistent with the extant literature (Maguire, Hardy, \& Lawrence, 2004; Perkman \& Spicer, 2007).

\section{REFERENCES}

Althusser, L. (1984). Ideology and ideological state apparatuses (Notes Toward an Investigation). In Essays on Ideology (B. Brewster, Trans., pp. 1-60). London: Verso.

Amabile, T., \& Gryskiewicz, S. S. (1987). Creativity in the R\&D laboratory. Greensboro, NC: Center for Creative Leadership.

Apple, M. W. (2004). Ideology and curriculum (3rd ed.). New York: Routledge-Falmer.

Archer, M., Bhaskar, R., Collier, A., Lawson, T., \& Norrie, A. (Eds.). (1998). Critical realism: Essential readings. London: Routledge.

Aronowitz, S. (2000). The knowledge factory: Dismantling the corporate university and creating true higher learning. Boston: Beacon.

Ayers, D. F. (2002). Developing climates for renewal in the community college: A case study of dissipative self-organization. Community College Journal of Research and Practice, 26, 165-185.

Ayers, D. F. (2005a). Neoliberal ideology in community college mission statements: A critical discourse analysis. Review of Higher Education, 28, 527-549.

Ayers, D. F. (2005b). Organizational climate in its semiotic aspect: A postmodern community college undergoes renewal. Community College Review, 33, 1-21.

Ayers, D. F., \& Carlone, D. (2007). Manifestations of neoliberal discourses in a local jobtraining program. International Journal of Lifelong Education, 26, 461-479.

Baker, G. A. (1992). Cultural leadership: Inside America's community colleges. Washington, DC: Community College Press.

Baker, G. A., \& Hoover, M. (1997). Personal assessment of the college environment. Raleigh: North Carolina State University.

Bass, B. M. (1998). Transformational leadership: Industrial, military, and educational impact. Mahwah, NJ: Erlbaum.

Bergquist, W. H. (1998). The postmodern challenge: Changing our community colleges. In J. S. Levin (Ed.), Organizational change in the community college: A ripple or a sea change (New Directions for Community Colleges, Vol. 102, pp. 99-106). San Francisco: JosseyBass. 
Bernstein, B. B. (1990). The structure of pedagogic discourse. London: Routledge.

Birnbaum, R. (2001). Management fads in higher education: Where they come from, what they do, why they fail. San Francisco: Jossey-Bass.

Bowles, S., \& Gintis, H. (1976). Schooling in capitalist America. New York: Basic Books.

Brint, S., \& Karabel, J. (1989). The diverted dream: Community colleges and the promise of educational opportunity in America, 1900-1985. New York: Oxford University Press.

Burns, J. M. (1978). Leadership. New York: Harper \& Row.

Cardenas, J. F. (2008). The changing landscape of education. Retrieved April 23, 2009, from http://www.compete.org/about-us/initiatives/compete2.0/skills/ the-changing-landscapeof-education/

Cervero, R. M., \& Wilson, A. L. (1994). Planning responsibly for adult education: A guide to negotiating power and interests. San Francisco: Jossey-Bass.

Cervero, R. M., \& Wilson, A. L. (2006). Working the planning table: Negotiating democratically for adult, continuing, and workplace education. San Francisco: Jossey-Bass.

Cervero, R. M., Wilson, A. L., \& Associates. (2001). Power in practice: Adult education and the struggle for knowledge and power in society (1st ed.). San Francisco: Jossey-Bass.

Chiapello, E., \& Fairclough, N. (2002). Understanding the new management ideology: A transdisciplinary contribution from critical discourse analysis and new sociology of capitalism. Discourse \& Society, 13, 185-208.

Chouliaraki, L., \& Fairclough, N. (1999). Discourse in late modernity: Rethinking critical discourse analysis. Edinburgh, UK: Edinburgh University Press.

Clark, B. R. (1960). The "cooling out" function in higher education. American Journal of Sociology, 65, 569-576.

Cohen, A. M., \& Brawer, F. B. (2003). The American community college (4th ed.). San Francisco: Jossey-Bass.

Dougherty, K. J. (1994). The contradictory college: The conflicting origins, impacts, and futures of the community college. Albany: State University of New York Press.

Engel, M. (2000). The struggle for control of public education: Market ideology vs. democratic values. Philadelphia, PA: Temple University Press.

Fairclough, N. (1989). Language and power. New York: Longman. Fairclough, N. (1995). Critical discourse analysis: The critical study of language. London: Longman. 
Fairclough, N. (2001). Critical discourse analysis as a method in social scientific research. In R. Wodak \& M. Meyer (Eds.), Methods of critical discourse analysis (pp. 121-138). Thousand Oaks, CA: SAGE.

Fairclough, N. (2003). Analysing discourse: Textual analysis for social research. New York: Routledge.

Fairclough, N. (2006). Language and globalization. New York: Routledge.

Flanagan, J. C. (1954). The critical incident technique. Psychological Bulletin, 51, 327-359.

Foucault, M. (1980). Power/knowledge: Selected interviews and other writings, 1972-1977 (C. Gordon, Trans.). New York: Pantheon.

Gee, J. P. (1999). An introduction to discourse analysis: Theory and method. London: Routledge.

Gee, J. P. (2001). Identity as an analytic lens for research in education. Review of Research in Education, 25, 99-123.

Giroux, H. A. (2002). Neoliberalism, corporate culture, and the promise of higher education: The university as a democratic public sphere. Harvard Educational Review, 72, 425-463.

Giroux, H. A., \& Giroux, S. S. (2004). Take back higher education: Race, youth, and the crisis of democracy in the post-civil rights era. New York: Palgrave Macmillan.

Gleazer, E. G. (1968). This is the community college. Boston: Houghton-Mifflin.

Gramsci, A. (1972). Selections from the prison notebooks of Antonio Gramsci (1st ed., Q. Hoare \& G. N. Smith, Eds. and Trans.). New York: International Publishers.

Grossberg, L. (2005). Caught in the crossfire: Kids, politics, and America's future. Boulder: Paradigm Publishers.

Gryskiewicz, S. S. (1999). Positive turbulence: Developing climates for creativity, innovation, and renewal. San Francisco: Jossey-Bass.

Halliday, M. A. K. (1978). Language as social semiotic: The social interpretation of language and meaning. Baltimore: University Park Press.

Halliday, M. A. K., \& Hasan, R. (1989). Language, context, and text: Aspects of language in a social-semiotic perspective (2nd ed.). New York: Oxford University Press.

Hardy, D. E., \& Katsinas, S. G. (2006). Using community college classifications in research: From conceptual model to useful tool. Community College Journal of Research and Practice, 30, 339-358. 
Heifetz, R. A., \& Linsky, M. (2002). Leadership on the line: Staying alive through the dangers of leading. Boston: Harvard Business School Press.

Hocker, J.L., \& Wilmot, W.W. (1985). Interpersonal Conflict (2nd ed.). Dubuque, IA: William C. Brown.

Holland, D. C. (1998). Identity and agency in cultural worlds. Cambridge, MA: Harvard University Press.

Jessop, B. (2007). State power: A strategic-relational approach. Malden, MA: Polity.

Jessop, B., Fairclough, N., \& Wodak, R. (Eds.). (2008). Education and the knowledge-based economy in Europe. Rotterdam: Sense Publishers.

Johnson, D. W., \& Johnson, F. P. (1994). Joining together: Group therapy and group skills (5th ed.). Boston: Allyn \& Bacon.

Johnson, L. (2002). Using the critical incident technique to assess gaming customer satisfaction. UNLV Gaming Research \& Review Journal, 6(2), 1-12.

Keatinge, D. (2002). Versatility and flexibility: Attributes of the critical incident technique in nursing research. Nursing and Health Sciences, 4, 33-39.

Kjaer, P., \& Pedersen, O. K. (2001). Translating liberalization: Neoliberalism in the Danish negotiated economy. In J. L. Campbell \& O. K. Pedersen (Eds.), Neoliberalism and institutional analysis (pp. 219-248). Princeton, NJ: Princeton University Press.

Levin, J. S. (2001). Globalizing the community college: Strategies for change in the twenty-first century. New York: Palgrave.

Levin, J. S. (2006). Faculty work: Tensions between educational and economic values. Journal of Higher Education, 77, 62-88.

Levin, J. S. (2007). Nontraditional students and community colleges: The conflict of justice and neoliberalism (1st ed.). New York: Palgrave Macmillan.

Levin, J. S., Kater, S., \& Wagoner, R. L. (2006). Community college faculty: At work in the new economy. New York: Palgrave Macmillan.

Likert, R. (1967). The human organization: Its management and value. New York: McGrawHill.

Litwin, G. H., \& Stringer, R. A. (1968). Motivation and organizational climate. Boston: Division of Research, Graduate School of Business Administration, Harvard University. 
Maguire, S., Hardy, C., \& Lawrence, T. B. (2004). Institutional entrepreneurship in emerging fields: HIV/AIDS treatment advocacy in Canada. Academy of Management Journal, 47, 657-679.

Marshall, G. (1998). A dictionary of sociology (2nd ed.). New York: Oxford University Press.

Pascale, R. T. (1999). Leading from a different place: Applying complexity theory to tap potential. In J. A. Conger, G. M. Spreitzer, \& E. E. Lawler, III (Eds.), The leader's change handbook: An essential guide to setting direction and taking action (pp. 195219). San Francisco: Jossey-Bass.

Pascale, R. T., Millemann, M., \& Gioja, L. (2000). Surfing the edge of chaos: The laws of nature and the new laws of business. New York: Crown Business.

Perkmann, M., \& Spicer, A. (2007). "Healing the scars of history": Projects, skills and field strategies in institutional entrepreneurship. Organization Studies, 28, 1101-1122.

Pettit, J. M., \& Ayers, D. F. (2002). Understanding conflict and climate in a community college. Community College Journal of Research and Practice, 26, 105-120.

Pincus, F. L. (1980). The false promises of community colleges: Class conflict and vocational education. Harvard Educational Review, 50, 332-361.

Radford, M. L. (2006). The critical incident technique and the qualitative evaluation of the connecting libraries and schools project. Library Trends, 55, 46-64.

Sayer, R. A. (2000). Realism and social science. London: SAGE.

Stringer, R. A. (2002). Leadership and organizational climate: The cloud chamber effect. Upper Saddle River, NJ: Prentice Hall.

van Leeuwen, T. (2009). Discourse as the recontextualization of social practice: A guide. In R. Wodak \& M. Meyer (Eds.), Methods of critical discourse analysis (2 ed., pp. 144-161). Thousand Oaks, CA: SAGE.

Wetherell, M., Yates, S., \& Taylor, S. (Eds.). (2001). Discourse theory and practice: A reader. London: SAGE.

Wodak, R. (2001). The discourse-historical approach. In R. Wodak \& M. Meyer (Eds.), Methods of critical discourse analysis (pp. 63-94). Thousand Oaks, CA: SAGE.

Wodak, R., \& Meyer, M. (Eds.). (2001). Methods of critical discourse analysis. London: SAGE.

Wodak, R., \& Meyer, M. (Eds.). (2009). Methods of critical discourse analysis (2nd ed.). Los Angeles: SAGE. 
Zwerling, S. (1976). Second best: The crisis of the community college. New York: McGraw-Hill. $\sim \sim \sim \sim \sim \sim \sim \sim$

David F. Ayers is an associate professor in the Department of Teacher Education and Higher Education at the University of North Carolina at Greensboro. 